STUDIA PRAWNO-EKONOMICZNE, T. CXIV, 2020

PL ISSN 0081-6841; e-ISSN 2450-8179 s. 195-216

https://doi.org/10.26485/SPE/2020/114/11

\title{
Mateusz BORKOWSKI*
}

iD https://orcid.org/0000-0003-0644-4764

\section{ECONOMIC SECURITY OF POLISH VOIVODESHIPS. MEASURING THE CONCEPT}

\begin{abstract}
Background: Economic security is currently considered as relevant aspect of every economy functioning. It can be stated that measuring its level is a kind of holistic approach to studying the national economy.

Research purpose: The aim of this article is to measure the level of economic security in Polish regions using both, a general approach as well as a more detailed one, considering selected economic dimensions, such as economic growth, wage growth, social security, food quality and environmental balance.

Methods: The paper considers Perkal's method to be the best taxonomic technique for constructing synthetic indicators and used it to do so.

Conclusions: The calculated synthetic indicators facilitates a linear ordering of the Polish Voivodeships in terms of economic security. Not only are Polish regions diversified relative to the general level of economic security, but also to the level of economic security according to several selected dimensions. What is more, it was possible to determine linear correlation coefficients between the indicator of general economic security and its measurement level in the selected dimensions. Social, economic and financial dimensions have the most significant impact on determining general economic security.
\end{abstract}

Keywords: economic security, dimensions of economic security, Perkal's method.

JEL classification: C38, E69, O10

\section{Introduction}

In today's world, the issue of economic security is essential. It can be stated that measuring its level is a kind of holistic approach to studying national economy. The level of economic security can be examined using a variety of methods,

* Bachelor Degree, University of Bialystok, Faculty of Economics and Finance (Master's degree student); e-mail: mateusz-borkowski-poczta@wp.pl 
for example: indicator analysis ${ }^{1}$, SWOT analysis ${ }^{2}$ or literature review ${ }^{3}$. What is more, its essence can be researched using both general or detailed approaches, the latter considering selecting dimensions ${ }^{4}$. Moreover, analysis of economic security can be conducted at the level of an entire country or its regions, with the Polish region being the Voivodeship5.

There is no generally accepted definition of economic security, which is due to the fact, that this issue is not only analyzed by economists, but also by researchers of other sciences. Z. Stachowiak ${ }^{6}$ claims that economic security is a "state of an economy, which ensures high efficiency of its functioning [...] and ability in opposing external influences, which can have negative impact on economic development”. E. Frejtag-Mika, Z. Kołodziejak and W. Putkiewicz consider this issue as the ability of the whole economic system to achieve a stable economic growth and development. K. Żukrowska ${ }^{8}$ defines this phenomenon as a state in which there is no threats toward the economic system functioning. K.A. Kłosiński ${ }^{9}$ recognizes that economic security is a combination of factors

1 Cf. M. Borkowski, Bezpieczeństwo Ekonomiczne Szwecji na tle państw OECD, Studia Ekonomiczne. Zeszyty Naukowe Uniwersytetu Ekonomicznego w Katowicach 2019/379 (17), pp. 7-31; M.N. Dudin, I.J. Fedorova, L.A. Ploticina, T.M. Tokmurzin, M.V. Beyyaeva, A.B. Ilyin, International Practices to Improve Economic Security, European Research Studies Journal 2018/1, pp. 459-467.

2 Cf. L. Kostecka-Tomaszewska, Economic security of China: the implications of the belt and road initiative, Optimum. Economic Studies 2018/4 (94), pp. 166-182; L. Kostecka-Tomaszewska, Economic Security of China In 21st centrury: SWOT analysis, in: H. Ribeiro, D. Naletina, A. Lorga de Silva (eds.), Economic and Social Development. Book of Proceedings, Economic and Social Development Conference 2018, pp. 486-496.

3 Cf. M. Leszczyńska, Bezpieczeństwo ekonomiczne państwa a rozwój gospodarki i społeczeństwa, Nierówności Społeczne a Wzrost Gospodarczy 2018/46 (4), pp. 289-298.

4 Cf. M. Kozłowska-Burdziak, Warunki bezpieczeństwa żywnościowego Polski (ze szczególnym uwzględnieniem województwa podlaskiego), Optimum. Economic Studies 2019/3 (97), pp. 33-48.

5 Throughout this paper, the terms "Voivodeship" and "region" will be used interchangeably.

6 Z. Stachowiak, Bezpieczeństwo ekonomiczne, in: Z. Stachowiak (ed.), Ekonomika obrony, Akademia Obrony Narodowej, Warszawa 1994, p. 189.

7 E. Frejtag-Mika, Z. Kołodziejak, W. Putkiewicz, Bezpieczeństwo ekonomiczne we wspótczesnym świecie, Stowarzyszenie na rzecz Ekorozwoju „Agro-Group”, Radom 1996, p. 28.

8 K. Żukrowska, Pojęcie bezpieczeństwa i jego ewolucja, in: K. Żukrowska, M. Grącik (eds.), Bezpieczeństwo międzynarodowe. Teoria i praktyka, Wydawnictwo Szkoła Główna Handlowa, Warszawa 2006, p. 21.

$9 \quad$ K.A. Kłosiński, Światowe determinanty bezpieczeństwa ekonomicznego, in: T. Guz, K.A. Kłosiński, P. Marzec (eds.), Bezpieczeństwo ekonomiczne państw, Polihymnia, Lublin-Tomaszów Mazowiecki 2006, p. 41. 
that affect the independence, stability and economic development of the economy. J. Yong ${ }^{10}$ admits that economic security is best defined as "the ability to provide a steady increase in the standard of living for the population through national economic development while maintaining economic independence". K. Księżopols$\mathrm{ki}^{11}$ and I. Jaźwiński ${ }^{12}$ both stated that economic security is the ability of an economic system to function efficiently. L. Kostecka-Tomaszewska ${ }^{13}$ on the basis of wide research of economic security developed the most holistic definition, which determines that economic security is "the ability of the economy to achieve a relatively fast and sustainable economic growth and create favorable conditions for raising the level of broadly understood well-being of citizens under free trade and free flow of factors of production".

The aim of this article is to measure Polish regions' level of economic security using both a general and a detailed approach. Perkal's method was applied in order to construct synthetic indicators.

\section{The dimensions of economic security}

Economic security is a multidimensional phenomenon. It should be noted that measuring and assessing its level is problematic due to the fact that there are many specific aspects of this issue. The basic components of economic security are economic and financial, social, food, energy, ecological, raw materials, military and political (Figure 1).

Financial security is related to both private and public finance, and its aim is to possess enough financial capital to function without any interferences ${ }^{14}$. The economic component is related to the regions' achieving stable economic development. What is important, Voivodeships' economic stability is crucial in this dimension. It can be considered as the basis for the economic development of regions ${ }^{15}$.

10 J. Yong, Economic Security: Redressing Imbalance, China Security 2007/2, pp. 66-67.

11 K. Księżopolski, Bezpieczeństwo ekonomiczne, Dom Wydawniczy ELIPSA, Warszawa 2011, p. 28.

12 I. Jaźwiński, Determinanty ksztattowania polskiego bezpieczeństwa gospodarczego. Wybrane aspekty, Przegląd Strategiczny 2011/1, p. 59.

13 L. Kostecka-Tomaszewska, Economic security of China: the implications ..., pp. 167-168.

14 K. Księżopolski, Bezpieczeństwo ekonomiczne..., p. 42.

15 M. Niedziólka, Bezpieczeństwo ekonomiczne państwa a funkcjonowanie otwartych funduszy emerytalnych, Zeszyty Naukowe Uniwersytetu Przyrodniczo-Humanistycznego w Siedlcach 2017/42 (115), p. 228. 
FIGURE 1: Dimensions of economic security

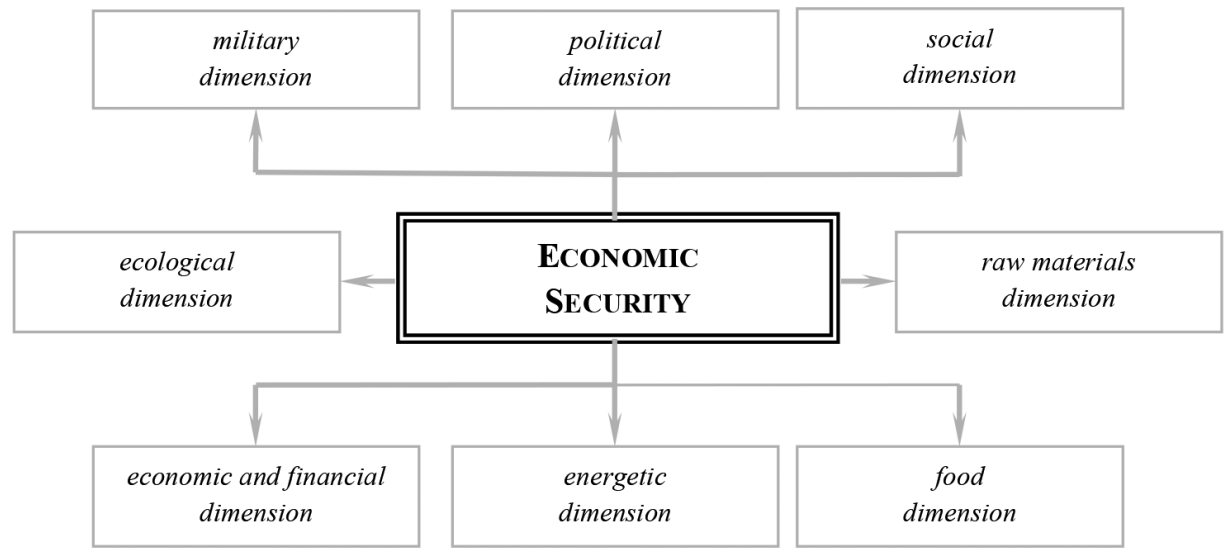

S o u r c e: own elaboration on the basis of: K. Księżopolski, Bezpieczeństwo ekonomiczne..., p. 42; S.E. Metelev, Economic Security as a Scientific Category: Theoretical and Methodical Aspect of Research, Annales Universitatis Mariae Curie-Skłodowska 2014/39 (2).

The social component of economic security, in regional terms, means the Voivodeships' ability to counteract threats in the social sphere ${ }^{16}$. The social dimension of economic security mainly relates to three issues: social security, health protection and education ${ }^{17}$. The theoretical development of this component was particularly influenced by the Copenhagen School, especially by B. Buzan ${ }^{18}$, who postulated that this dimension of economic security is as important as the others ${ }^{19}$.

Food security is the ability of the economic system to guarantee both the economic and physical availability of food goods ${ }^{20}$ in manner that is both stable and undisturbed ${ }^{21}$. What is more, the food goods supplied should be of a high

J. Gierszewski, Bezpieczeństwo społeczne jako dziedzina bezpieczeństwa narodowego, Historia i Polityka 2018/23 (30), p. 22.

17 A. Skrabacz, Uwarunkowania tworzenia bezpieczeństwa społecznego w XXI wieku, in: A. Skrabacz, S. Sulowski (eds.), Bezpieczeństwo społeczne. Pojęcie, uwarunkowania, wyzwania, Elipsa, Warszawa 2012, p. 53.

B. Buzan, O. Waever, J. de Wilde, Security: A New Framework for Analysis, Lynne Rienner Publishers, London 1998.

19 M. Stone, Security According to Buzan: A Comprehensive Security Analysis, Security Discussion Papers. Series 1 2009/9, p. 10.

20 A. Mikuła, Bezpieczeństwo żywnościowe Polski, Roczniki Ekonomii Rolnictwa i Rozwoju Obszarów Wiejskich 2012/99/4, pp. 39-40.

21 R. Grochowska, Specyfika koncepcji bezpieczeństwa żywnościowego jako „problemu bez rozwiązania”, Zagadnienia Ekonomiki Rolnej 2014/3, p. 96. 
quality, which means that, not only must food goods meet the needs and preferences of customers, but also provide them adequate nutrition for a healthy and active lifestyle ${ }^{22}$. It can be concluded that the quality of food security in Voivodeships is reflected by the quality of agricultural production, though this is an admitted simplification as not all agricultural produce is consumed in the same region where it was produced.

FIGURE 2: Diversification of Polish Voivodeships according to level of economic security

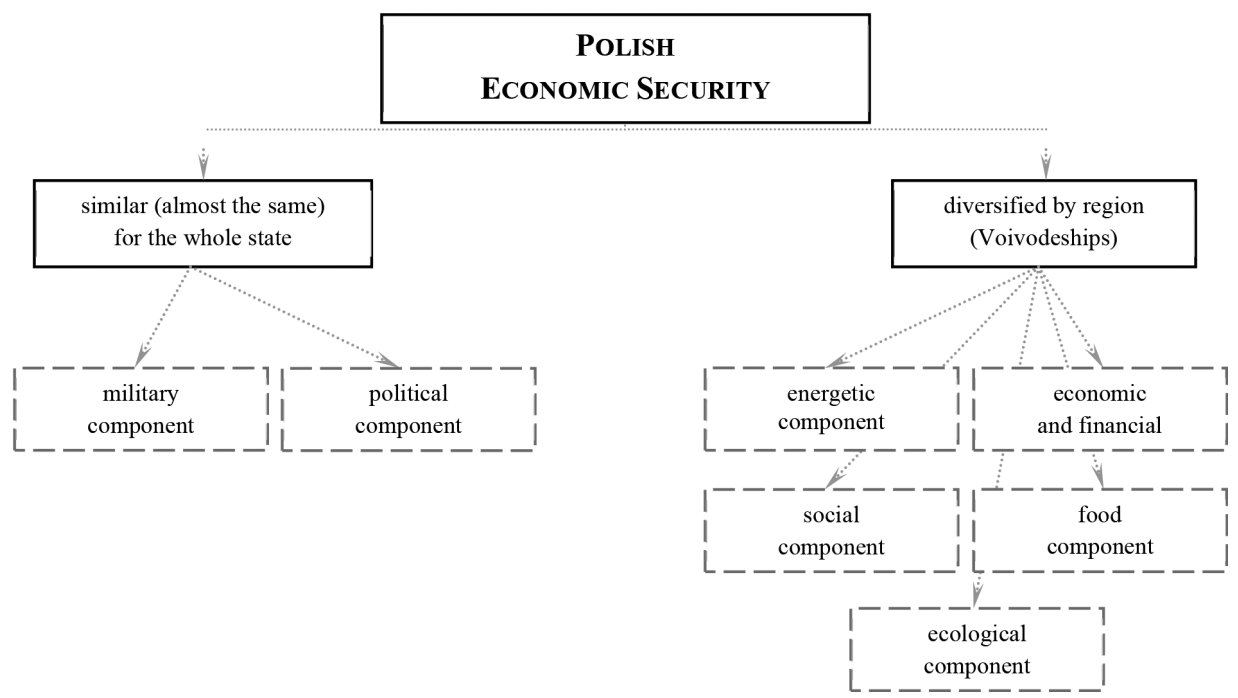

S o u r c e: own elaboration.

Energy security is the ability of the state (but also regions of the country) to provide an adequate supply of energy goods, which absorbs the whole demand $^{23}$. In case of this dimension there are two important aspects: the availability of energetic goods at any time and the level of prices, which should allow normal consumption of these goods ${ }^{24}$.

22 H. Pieters, A. Vandeplas, A. Guariso, N. Francken, A. Sarris, J. Swinnen, N. Gerber, J. von Braun, M. Torero, Perspectives on relevant concepts related to food and nutrition security, Foodsecure, Working Paper 2012-01, pp. 1-4.

23 T.M. Mkrtchyan, State Economic Security System and Its Components, 4th Int'1 Conference on Research in Humanities, Sociology \& Corporate Social Responsibility (RHSCSR'15), Penang 2015, p. 11.

24 K. Żukrowska, Bezpieczeństwo międzynarodowe. Przegląd aktualnego stanu, Wydawnictwo IUSatTAX, Warszawa 2011, p. 397. 
The ecological component of economic security is associated with broadly understood protection and respect for the natural environment ${ }^{25}$. This dimension of economic security is strongly related to the food and energy components. Ecological security is maintained in a situation where the production of food and energy goods takes place without harm for the natural environment.

Military security refers to the ability of the entire economy to resist and counteract external negative influences ${ }^{26}$. It should be noted that this component of economic security refers to the whole economy. Therefore, this dimension should be only researched at the level of the whole country (Figure 2).

The level of political security is also not diversified according to individual Voivodeships, as it also applies to the entire country (Figure 2). The political dimension of economic security is linked to the existence of adequate legal regulations that guarantee the protection of territorial integrity and political independence ${ }^{27}$.

FIGURE 3: Dimensions of economic security in Polish provinces - concept of division

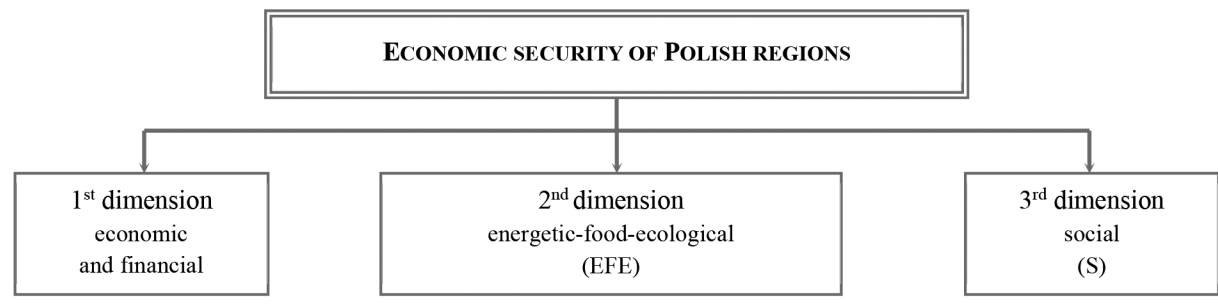

S o u r c e: own elaboration.

This paper divides the economic security of the Polish regions along three dimensions (Figure 3). The first dimension is related to economic and financial security. The second one combines the four types of economic security: raw materials, energy, food and ecological. This is due to the fact that these four components are closely connected, and it is difficult to analyze them separately. The third dimension refers to the social aspects of economic security.

25 N. Reznikova, Ecological imperatives for extension of globalisation processes: problem of economic security, Інвестиції: практикатадосвід 2016/21, pp. 23-24.

B. Stachowiak, Z. Stachowiak, Kontrowersje i dylematy rozwiazania problemu bezpieczeństwa ekonomicznego w Polsce, Zeszyty Naukowe Akademii Obrony Narodowej 2014/3 (96), p. 193.

27 L. Kostecka-Tomaszewska, Economic Security of China In 21st centrury: SWOT analysis..., p. 488. 


\section{Research method}

The article applies the method developed by J. Perkal in $1953^{28}$, which is one of many taxonomic techniques that attempts to determine the value of a synthetic indicator of the level of economic security ${ }^{29}$. This study adopts the division of economic security into three dimensions, therefore three synthetic indicators will be calculated. Synthetic indicators of the general level of economic security in Polish Voivodeships were estimated based on the indicators of all three dimensions of this phenomenon. The procedure for creating the synthetic measure will be demonstrated using the example of one of the economic security dimensions. The calculation of synthetic measure using Perkal's method consisted in the following steps:

Step 1. Selection of diagnostic indicators.

Step 2. Analysis of selected variables.

Step 2.1. Diagnostic variables should have widely recognized importance. It is important to choose indicators, which have commonly recognized meaning ${ }^{30}$.

Step 2.2. Selected variables should also meet statistical criteria. Their discriminatory abilities ${ }^{31}$ should be examined, using for example one of the coefficients of variation. In this paper it is applied, that classical coefficient of variation $^{32}$ should be equal or higher than $10 \%$ for variables ${ }^{33}$. Moreover, variables should be statistically important, which means that their distributions should be normal or symmetrical. What is more, variables with positively skewed distributions are also accepted in this study, due to their ability to best determine objects from the analysed set ${ }^{34}$. Diagnostic variables should also be presented in the form of intensity indicators ${ }^{35}$.

28 Trans Humana, Białystok 2014, p. 65.

31 E. Nowak, Problemy doboru zmiennych do modelu ekonometrycznego, Państwowe Wydawnictwo Naukowe, Warszawa 1984, pp. 10-12.

32 Ratio of the standard deviation to the arithmetic mean.

33 H. Kruk, A. Waśniewska, Application of the Perkal method for assessing competitiveness of the countries of Central and Eastern Europe, Oeconomia Copernicana 2017/3, p. 343.

34 D. Perlo, Modelowanie..., p. 66.

35 E. Roszkowska, M. Filipowicz-Chomko, Ocena rozwoju społecznego województw w latach 2005 oraz 2013 w kontekście realizacji koncepcji zrównoważonego rozwoju z wykorzystaniem metody TOPSIS, Ekonomia i Środowisko 2016/57, p. 138. 
Step 2.3. Lastly, the correlation matrix of the selected variables should be analysed. Stimulants ${ }^{36}$ and destimulants ${ }^{37}$ should be positively correlated between each other. What is more, correlation between stimulants and destimulants should be negative. Furthermore, variables should not be excessively correlated with each other. In order to eliminate too strongly correlated diagnostic measures, the inverse correlation matrix method was applied ${ }^{38}$. The disqualification of explanatory variables was carried out in steps, until an inverted correlation matrix was obtained, where each diagonal element was equal or lower than 10 .

Step 3. Transformation of destimulants into stimulants according to formula (1).

$$
x_{i j}^{(+)}=-x_{i j}^{(-)}
$$

$i$ - number of object, in this paper number of Voivodeship $(1,2, \ldots, 16)$

$j$ - number of diagnostic variable of selected dimension of economic security $(1,2, \ldots, m)$

$x_{i j}^{(+)}$- value of transformed destimulant into stimulant of $j$-indicator on $i$-object $x_{i j}^{(-)}$- value of destimulant of $j$-indicator on $i$-object

Step 4. Normalisation of the values of selected variables. The classical standardisation method was performed (2).

$$
n_{i j}=\frac{x_{i j}-\bar{x}_{j}}{s_{j}}
$$

$\bar{x}_{j}-$ arithmetic mean of $j$-variable

$s_{j}-$ standard deviation of $j$-variable

Step 5. Calculation of synthetic measure as an arithmetic mean of selected indicators' normalized values of ${ }^{39}(3)$.

$$
X_{i}=\frac{\sum_{j=1}^{m} n_{i j}}{m}
$$

36 Variables, of which higher values indicate a higher level of researched phenomenon.

37 Variables, of which higher values indicate a lower level of researched phenomenon.

38 F. Chybalski, Analizy wielowymiarowe, in: I. Staniec (ed.), Metody ilościowe w zarzadzaniu organizacja, Wydawnictwo C.H. Beck, Warszawa 2013, p. 104.

39 B. Namyślak, Ocena potencjału kulturalnego największych miast Polski, Wiadomości Statystyczne $2013 / 6$, p. 25. 
$X_{i}$ - value of synthetic measure in $X$-dimension of economic security on $i$-object $m$ - the number of indicators of $X$-dimension of economic security

Step 6. Division of Voivodeships into four typological groups using the arithmetic mean $(\bar{X})$ and the standard deviation $\left(s_{X}\right)^{40}$.

Group I - very high level of economic security in $X$-dimension

$$
X_{i} \geq \bar{X}+s_{X}
$$

Group II - high level of economic security in $X$-dimension

$$
\bar{X}+s_{X}>X_{i} \geq \bar{X}
$$

Group III - moderate level of economic security in $X$-dimension

$$
\bar{X}>X_{i} \geq \bar{X}-s_{X}
$$

Group IV - threatened level of economic security in $X$-dimension

$$
\bar{X}-s_{X}>X_{i}
$$

Step 7. Calculating the differences between normalized values of selected variables and the value of estimated synthetic measure $(8)^{41}$.

$$
C_{i j}=n_{i j}-X_{i}
$$

In order to facilitate the analysis of the proportionality of the structure of synthetic indicators formula (9) was applied ${ }^{42}$.

$$
H_{i}=\sum_{j=1}^{m}\left|C_{i j}\right|
$$

$H_{i}-$ structure and proportionality index for $i$-object (Voivodeship)

40 E. Nowak, Metody taksonomiczne w klasyfikacji obiektów społeczno-gospodarczych, Państwowe Wydawnictwo Ekonomiczne, Warszawa 1990, p. 91.

41 D. Perlo, Environmental Quality..., p. 164.

42 B. Namyślak, Ocena potencjału..., p. 25. 


\section{Selection of diagnostic variables}

This paper used data from Local Data Bank (Statistics Poland) ${ }^{43}$. The year 2017 was selected as the period of research, due to it being the most recently available statistical data.Twelve detailed indicators were initially qualified from the set of economic and financial dimension of economic security variables. After statistical analysis, seven variables remained in this set (Table 1). Indicators: $\mathrm{EF}_{1}, \mathrm{EF}_{2}$, $\mathrm{EF}_{3}, \mathrm{EF}_{5}$ and $\mathrm{EF}_{7}$ are stimulants, while $\mathrm{EF}_{4}$ and $\mathrm{EF}_{6}$ are destimulants.

During the statistical analysis, five variables explaining the energy-food-ecological dimension of economic security were selected from a set of eight indicators (Table 1). Diagnostic variables of this dimension include: two stimulants $\left(\mathrm{EFE}_{3}, \mathrm{EFE}_{4}\right)$ and three destimulants $\left(\mathrm{EFE}_{1}, \mathrm{EFE}_{2}, \mathrm{EFE}_{5}\right)$.

Table 1 also presents five indicators, selected from among eighteen, of the social dimension of economic security. Variables: $\mathrm{S}_{1}, \mathrm{~S}_{2}, \mathrm{~S}_{3}$ and $\mathrm{S}_{5}$ belong to the stimulant set. $\mathrm{S}_{3}$ is a destimulant.

TABLE 1: Selected indicators of economic security

\begin{tabular}{|c|c|c|}
\hline Symbol & Description of selected indicator & $\begin{array}{l}\text { Type } \\
\text { of variable }\end{array}$ \\
\hline 1 & 2 & 3 \\
\hline \multicolumn{3}{|c|}{ Economic and Financial dimension (EF) } \\
\hline $\mathrm{EF}_{1}$ & $\begin{array}{l}\text { net financial results of enterprises in the Voivodeship as } \\
\text { a percentage of total financial results of enterprises in Poland (\%) }\end{array}$ & stimulant \\
\hline $\mathrm{EF}_{2}$ & $\begin{array}{l}\text { gross value of fixed assets in the national economy per capita } \\
\text { (PLN) }\end{array}$ & stimulant \\
\hline $\mathrm{EF}_{3}$ & investments per capita (PLN) & stimulant \\
\hline $\mathrm{EF}_{4}$ & rate of registered unemployment (\%) & destimulant \\
\hline $\mathrm{EF}_{5}$ & $\begin{array}{l}\text { expenditure on innovation activities in enterprises for one active } \\
\text { person (PLN) }\end{array}$ & stimulant \\
\hline $\mathrm{EF}_{6}$ & $\begin{array}{l}\text { percentage of persons employed in section A - agriculture, } \\
\text { hunting, forestry, fishing }(\%)\end{array}$ & destimulant \\
\hline $\mathrm{EF}_{7}$ & $\begin{array}{l}\text { percentage of persons employed in sections } \mathrm{G}-\mathrm{J}-\text { market } \\
\text { services }(\%)\end{array}$ & stimulant \\
\hline
\end{tabular}

${ }_{43}$ Local Data Bank, Statistics Poland, https://bdl.stat.gov.pl/BDL/start; accessed 22.11.2019. 


\begin{tabular}{|c|c|c|}
\hline 1 & 2 & 3 \\
\hline \multicolumn{3}{|c|}{ Energy-Food-Ecological dimension (EFE) } \\
\hline $\mathrm{EFE}_{1}$ & emission of gas pollution in tones per $1 \mathrm{~km}^{2}\left(\mathrm{t} / \mathrm{km}^{2}\right)$ & destimulant \\
\hline $\mathrm{EFE}_{2}$ & emission of dust pollution in tones per $1 \mathrm{~km}^{2}\left(\mathrm{t} / \mathrm{km}^{2}\right)$ & destimulant \\
\hline $\mathrm{EFE}_{3}$ & share of renewable energy in total electricity production (\%) & stimulant \\
\hline $\mathrm{EFE}_{4}$ & certified organic farms - share of UAA in total UAA $(\%)$ & stimulant \\
\hline $\mathrm{EFE}_{5}$ & $\begin{array}{l}\text { consumption of mineral fertilizers in } \mathrm{kg} \text { per } 1 \text { ha of arable land } \\
(\mathrm{kg} / \mathrm{ha})\end{array}$ & destimulant \\
\hline \multicolumn{3}{|c|}{ Social dimension $(\mathbf{S})$} \\
\hline $\mathrm{S}_{1}$ & net enrollment rate - general secondary schools (\%) & stimulant \\
\hline $\mathrm{S}_{2}$ & university graduates for 10,000 population (persons) & stimulant \\
\hline $\mathrm{S}_{3}$ & number of deaths of newborns per 1 thousand births (persons) & destimulant \\
\hline $\mathrm{S}_{4}$ & $\begin{array}{l}\text { share of the number of persons with higher education in the total } \\
\text { population }(\%)\end{array}$ & stimulant \\
\hline $\mathrm{S}_{5}$ & $\begin{array}{l}\text { expenditure of Voivodeship budgets on healthcare per capita } \\
\text { (PLN) }\end{array}$ & stimulant \\
\hline
\end{tabular}

S o u r c e: own elaboration.

All of the variables presented in Table 1 were statistically and substantially positively verified. From a set of thirty-eight variables, seventeen were selected for the next stage of the research.

\section{Research results}

The estimated values of synthetic measures of the economic and financial dimensions of economic security are presented in Table 2. In 2017, the strongest region in terms of the analysed indicators was the Mazowieckie Voivodeship (with a synthetic measure of 2.199). Moreover, the difference between this Voivodeship and the Dolnośląskie Voivodeship ( $2^{\text {nd }}$ in ranking) is significant (approximately 1.515). It can be concluded, that Mazowieckie Voivodeship is undeniably the best from all of Polish regions in this selected dimension of economic security. The weakest region in terms of the analyzed synthetic variable is the Lubelskie Voivodeship (with a synthetic measure of -1.118). 
TABLE 2: Ranking of Voivodeships in terms of the level of economic security in the economic and financial dimension

\begin{tabular}{|l|c|c|}
\hline Voivodeship & EF & rank \\
\hline Mazowieckie & 2.199 & 1. \\
\hline Dolnośląskie & 0.684 & 2. \\
\hline Wielkopolskie & 0.626 & 3. \\
\hline Pomorskie & 0.599 & 4. \\
\hline Śląskie & 0.596 & 5. \\
\hline Łódzkie & 0.242 & 6. \\
\hline Lubuskie & 0.170 & 7. \\
\hline Małopolskie & 0.133 & 8. \\
\hline Zachodniopomorskie & 0.087 & 9. \\
\hline Opolskie & -0.232 & 10. \\
\hline Kujawsko-Pomorskie & -0.481 & 11. \\
\hline Podlaskie & -0.790 & 12. \\
\hline Warmińsko-Mazurskie & -0.835 & 13. \\
\hline Podkarpackie & -0.866 & 14. \\
\hline Świętokrzyskie & -1.015 & 15. \\
\hline Lubelskie & -1.118 & 16. \\
\hline Group I & \multicolumn{2}{|l}{} \\
\hline Group II & \multicolumn{2}{|l}{} \\
\hline Group III & \multicolumn{2}{|l}{} \\
\hline Group IV & \\
\hline
\end{tabular}

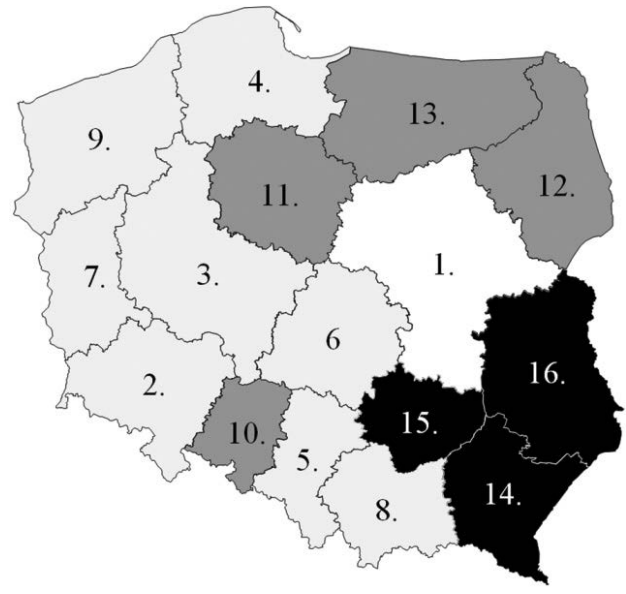

S o u r c e: own elaboration on the basis of statistical data.

Only the Mazowieckie Voivodeship belongs to the group with very high economic and financial security. The next six Voivodeships: Pomorskie, Śląskie, Łódzkie, Lubuskie, Małopolskie and Zachodniopomorskie - form a group of regions with high security in the economic and financial dimension. A moderate level of security was observed in four Voivodeships: Opolskie, Kujawsko-Pomorskie, Podlaskie and Warmińsko-Mazurskie. Three voivodeships - Podkarpackie, Świętokrzyskie and Lubelskie - demonstrated a threatened level of economic security. The division of Voivodeships into four typological groups indicates that, excepting the Mazowieckie Voivodeship ${ }^{44}$, the western Voivodeships have a higher level of economic and financial security than the eastern Voivodeships.

44 It may also be relevant to point out that it may not be the Mazowieckie Voivodeship as it is the economic strength of Warsaw. If Warsaw is removed, it may be possible that Mazowieckie will have much lower economic security. 
Chart 1 presents the structure and proportionality indexes of the of the synthetic measure calculated in financial and economic dimension. The results of the analysis show that the least balanced inner structure of this synthetic measure occurs in the Mazowieckie Voivodeship, while the most balanced inner structure of synthetic variable occurs in the Podlaskie Voivodeship.

CHART 1: Structure and proportionality indexes of the synthetic measure of economic and financial security

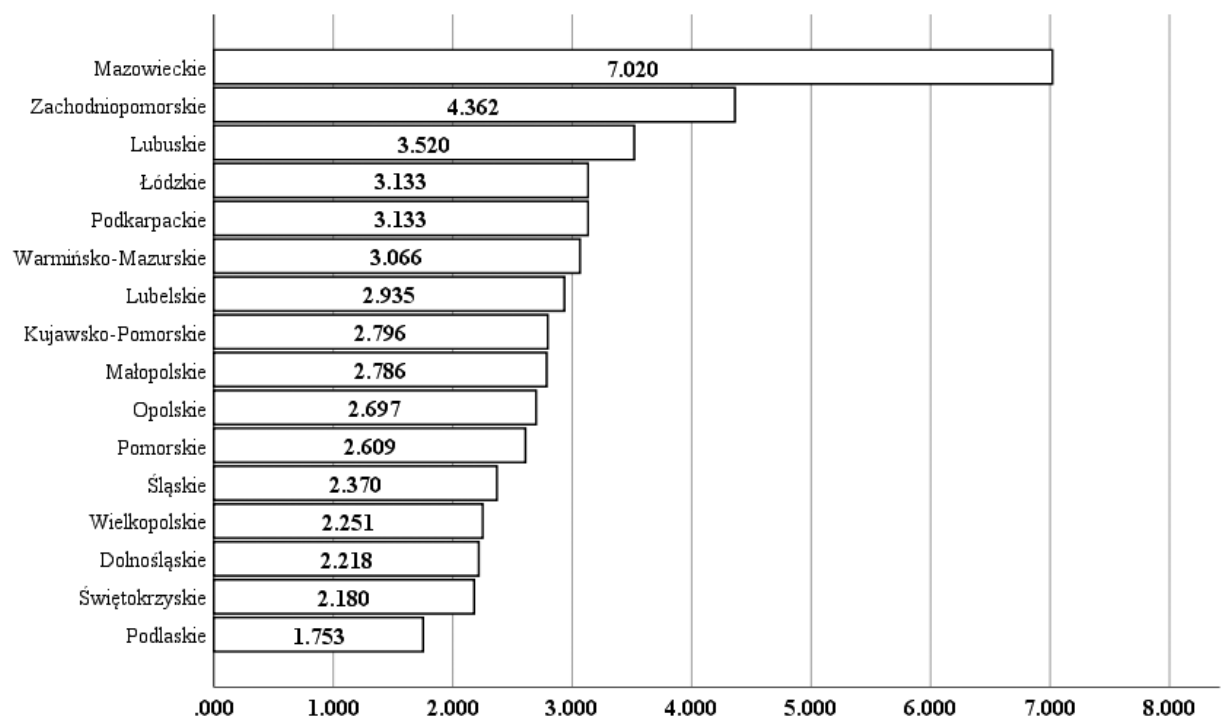

S o u r c e: own elaboration.

The proportionality indexes obtained from these results of the indicate that there could be a statistical relationship between the value of economic and financial security synthetic variables and the degree of proportionality of the structure of these measures. The Pearson's linear correlation coefficient between values of these two indices is equal to 0.590 and is statistically significant ( $p$-value $<0,02$ ). This means that there is a significant moderate, positive statistical relationship between these variables. Bearing that in mind, it can be assumed that Voivodeships with a higher level of economic security in the economic and financial dimension have less balanced structures of synthetic indicators.

The ranking of Voivodeships in terms of their energy-food-ecological security level is presented in Table 3. The highest value of synthetic measure in this dimension belongs to the Warmińsko-Mazurskie Voivodeship (1.362), 
the lowest to the Śląskie Voivodeship $(-1.610)$. The Voivodeships with very high level of energy-food-ecological security are: Warmińsko-Mazurskie, Podlaskie and Zachodniopomorskie. Four Voivodeships: Lubuskie, Podkarpackie, Pomorskie, and Małopolskie - belong to the group of high level of economic security in terms of energy-food-ecological security. An average level of security was observed in six regions: Lubelskie, Mazowieckie, Świętokrzyskie, Kujawsko-Pomorskie, Wielkopolskie and Dolnośląskie Voivodeships. The regions were at risk in terms of economic security according to the energy-food-ecological criteria: Łódzkie, Opolskie and Śląskie.

TABLE 3: Ranking of Voivodeships in terms of the level of economic security according to the energy-food-ecological criteria

\begin{tabular}{|l|c|c|}
\hline Voivodeship & EFE & rank \\
\hline Warmińsko-Mazurskie & 1.362 & 1. \\
\hline Podlaskie & 0.792 & 2. \\
\hline Zachodniopomorskie & 0.738 & 3. \\
\hline Lubuskie & 0.703 & 4. \\
\hline Podkarpackie & 0.488 & 5. \\
\hline Pomorskie & 0.338 & 6. \\
\hline Małopolskie & 0.001 & 7. \\
\hline Lubelskie & -0.088 & 8. \\
\hline Mazowieckie & -0.090 & 9. \\
\hline Świętokrzyskie & -0.130 & 10. \\
\hline Kujawsko-Pomorskie & -0.273 & 11. \\
\hline Wielkopolskie & -0.326 & 12. \\
\hline Dolnośląskie & -0.348 & 13. \\
\hline Łódzkie & -0.746 & 14. \\
\hline Opolskie & -0.813 & 15. \\
\hline Śląskie & -1.610 & 16. \\
\hline Group I & \multicolumn{2}{|l}{} \\
\hline Group II & \multicolumn{2}{|l}{} \\
\hline Group III & \multicolumn{2}{|l}{} \\
\hline Group IV &
\end{tabular}

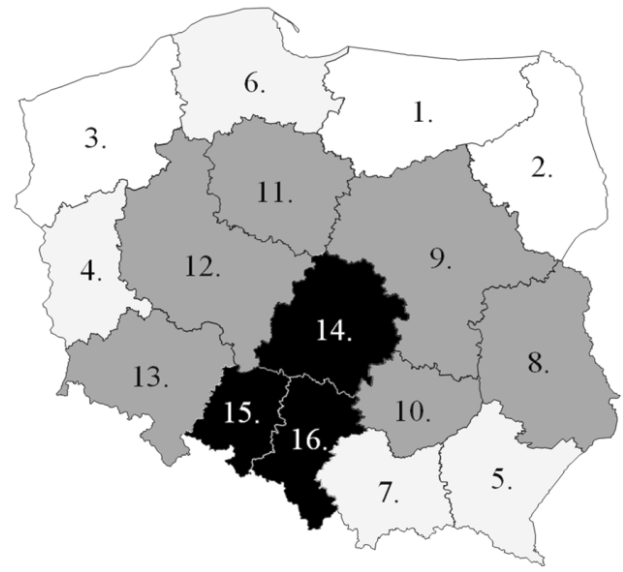

S o u r c e: own elaboration on the basis of statistical data.

Chart 2 presents the structure and proportionality indexes of the of the synthetic measure calculated in theenergy-food-ecological dimension. The conducted analysis indicates that the least balanced inner structure of the synthetic measure occurs in the Śląskie Voivodeship, with the most balanced structure observed in the Podlaskie Voivodeship. 
CHART 2: Structure and proportionality indexes of the synthetic measure of energy-food-ecological security

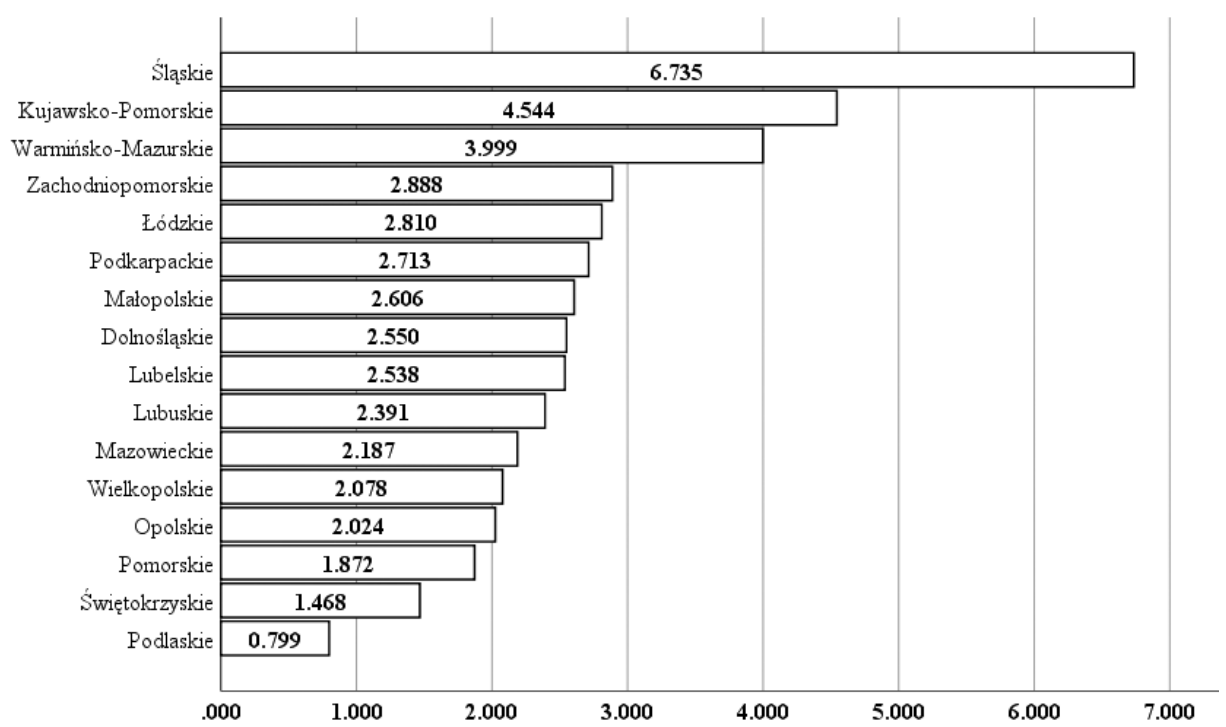

S o u r c e: own elaboration.

The values of synthetic variable of economic security in the social dimension is presented in Table 4. The Mazowieckie Voivodeship holds first place in the ranking of economic security in social dimension. Again, difference between value of synthetic measure for this region and second Voivodeship in ranking (Małopolskie) is significant, and is approximately equal to 1.368 . The lowest level of social security was observed in Kujawsko-Pomorskie Voivodeship (-0.796).

The Mazowieckie Voivodeship is the only one with a very high level of social security. Six Voivodeships: Małopolskie, Pomorskie, Podkarpackie, Dolnośląskie, Wielkopolskie and Podlaskie - have a high level of social component of economic security. The average level of social dimension of security was noted in the following regions: Śląskie, Świętokrzyskie, Łódzkie, Lubelskie, Warmińsko-Mazurskie, Zachodniopomorskie and Opolskie Voivodeships. Lubuskie and Kujawsko-Pomorskie Voivodeships belongs to the group of regions with unsafe level of economic security in social dimension. 
TABLE 4: Ranking of Voivodeships in terms of the level of economic security according to the social dimension

\begin{tabular}{|l|c|c|}
\hline Voivodeship & S & rank \\
\hline Mazowieckie & 1.945 & 1. \\
\hline Małopolskie & 0.577 & 2. \\
\hline Pomorskie & 0.554 & 3. \\
\hline Podkarpackie & 0.332 & 4. \\
\hline Dolnośląskie & 0.138 & 5. \\
\hline Wielkopolskie & 0.057 & 6. \\
\hline Podlaskie & 0.013 & 7. \\
\hline Śląskie & -0.095 & 8. \\
\hline Świętokrzyskie & -0.167 & 9. \\
\hline Łódzkie & -0.197 & 10. \\
\hline Lubelskie & -0.199 & 11. \\
\hline Warmińsko-Mazurskie & -0.382 & 12. \\
\hline Zachodniopomorskie & -0.408 & 13. \\
\hline Opolskie & -0.613 & 14. \\
\hline Lubuskie & -0.760 & 15. \\
\hline Kujawsko-Pomorskie & -0.796 & 16. \\
\hline Group I & & \\
\hline Group II & \multicolumn{2}{|l}{} \\
\hline Group III & \multicolumn{2}{|l}{} \\
\hline Group IV & & \\
\hline
\end{tabular}

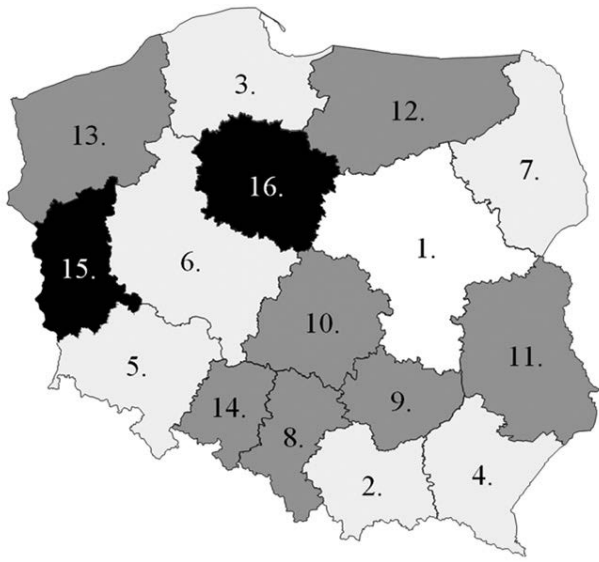

S o u r c e: own elaboration on the basis of statistical data.

Chart 3 presents the structure and proportionality indexes of the of the synthetic measure calculated in terms of thesocial component of economic security. The conducted analyses indicate that the least balanced inner structure of the synthetic measure occurs in the Warmińsko-Mazurskie Voivodeship, with the balanced structure observed in the Śląskie Voivodeship.

The estimated values of the synthetic measure of general economic security level were presented in Table 5. The first position is occupied by the Mazowieckie Voivodeship (with a synthetic variable at 1.414). It should be noted that it is difficult to identify the weakest region in terms of economic security. This is due to the fact, that for four Voivodeships synthetic indicator of economic security is of a similarly low level. These Voivodeships are: Świętokrzyskie, where synthetic measure is equal to -0.505 , Kujawsko-Pomorskie $(-0.512)$, Opolskie $(-0.515)$, and Lubelskie $(-0.545)$. 
CHART 3: Structure and proportionality indexes of the synthetic measure of social security

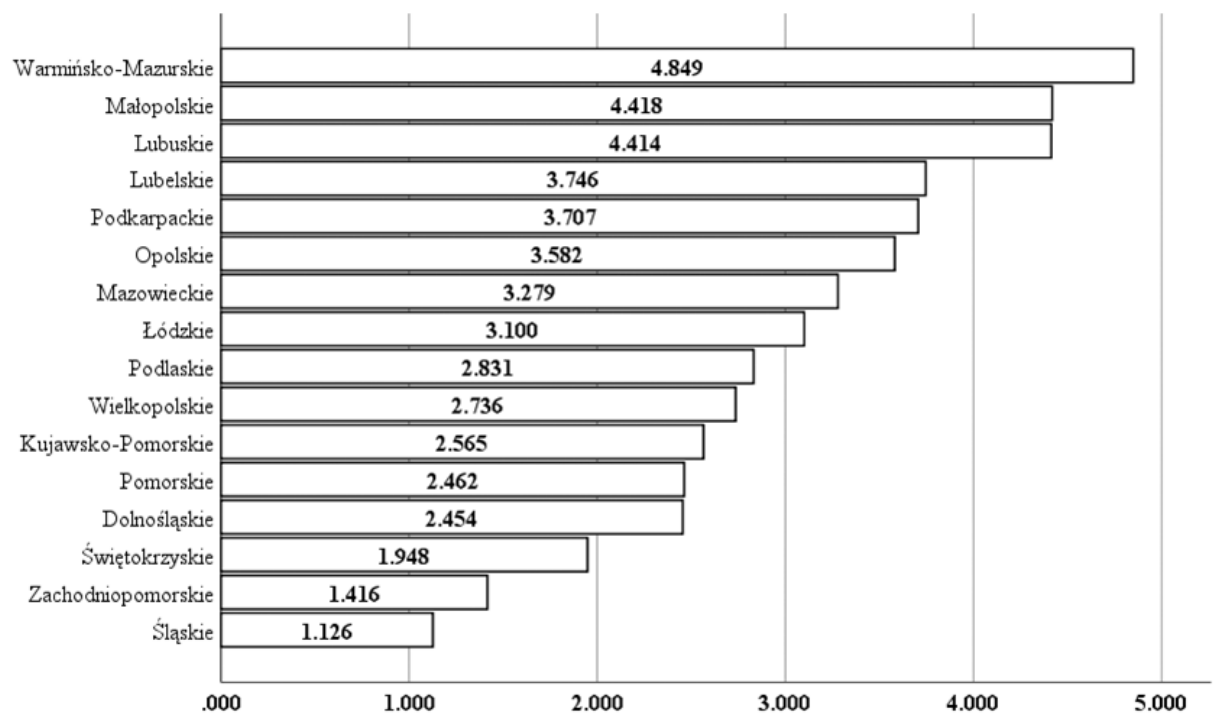

S o u r c e: own elaboration.

TABLE 5: Ranking of Voivodeships in terms of the level of economic security

\begin{tabular}{|l|c|c|}
\hline Voivodeship & ES & rank \\
\hline Mazowieckie & 1.451 & 1. \\
\hline Pomorskie & 0.509 & 2. \\
\hline Małopolskie & 0.225 & 3. \\
\hline Dolnośląskie & 0.220 & 4. \\
\hline Wielkopolskie & 0.178 & 5. \\
\hline Zachodniopomorskie & 0.133 & 6. \\
\hline Lubuskie & 0.054 & 7. \\
\hline Warmińsko-Mazurskie & -0.056 & 8. \\
\hline Podlaskie & -0.088 & 9. \\
\hline Podkarpackie & -0.115 & 10. \\
\hline Łódzkie & -0.178 & 11. \\
\hline Śląskie & -0.256 & 12. \\
\hline Świętokrzyskie & -0.505 & 13. \\
\hline Kujawsko-Pomorskie & -0.512 & 14. \\
\hline Opolskie & -0.515 & 15. \\
\hline Lubelskie & -0.545 & 16. \\
\hline Group I & & \\
\hline Group II & & \\
\hline Group III & \multicolumn{2}{|l}{} \\
\hline Group IV & \multicolumn{2}{|l}{} \\
\hline Source: own & & \\
\hline
\end{tabular}

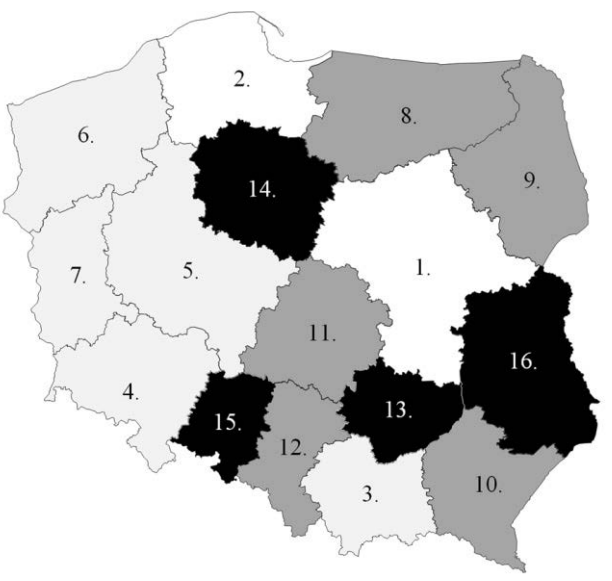

S o u r c e: own elaboration on the basis of statistical data. 
What is worth mentioning is that the synthetic measure of economic security for Polish regions (excluding Mazowieckie Voivodeship) assume values in the approximate range of $(0.500,0.500)$. With this in mind, it can be concluded that the level of diversification of economic security across the Polish regions is moderate.

Chart 4 presents the structure and proportionality indexes of the of the synthetic measure of economic security. The results of the analysis demonstrate that the least balanced internal structure of this synthetic measure occurs in the Mazowieckie Voivodeship. The most balanced inner structure of synthetic variable is for the Pomorskie Voivodeship.

CHART 4: Structure and proportionality indexes of the synthetic measure of economic security

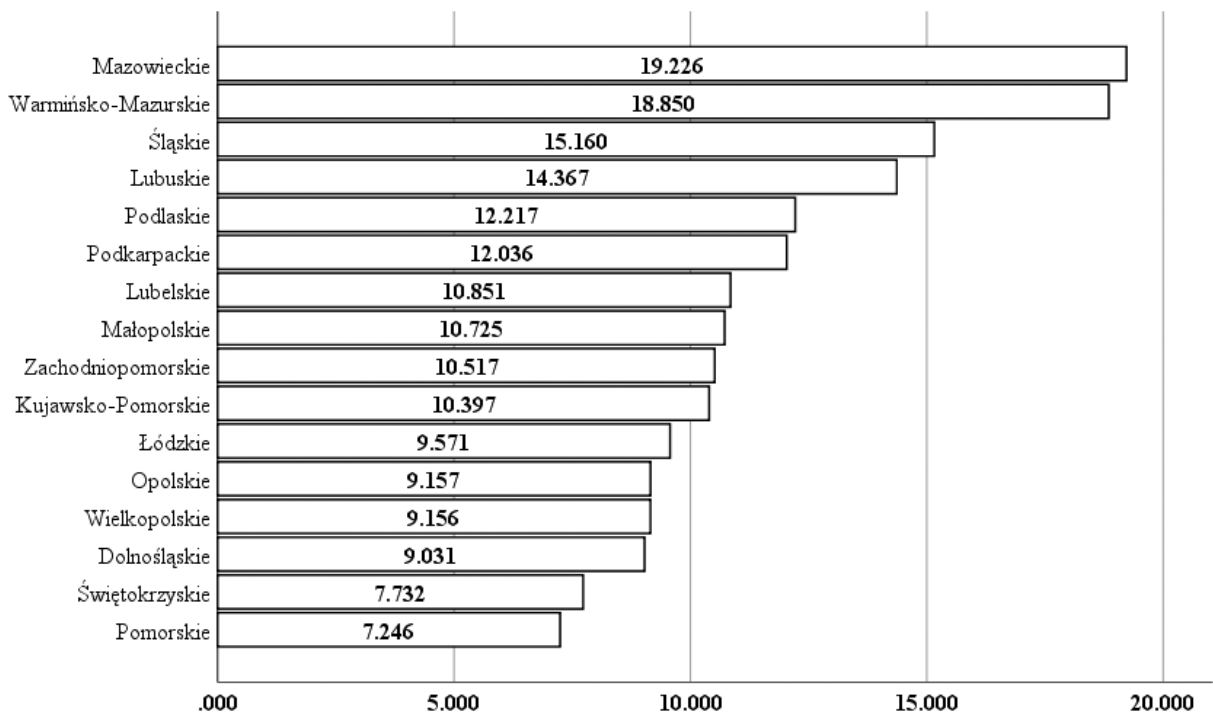

S o u r c e: own elaboration.

Lastly, Pearson's linear correlation coefficients between the synthetic indicator of general economic security and synthetic variables of economic security according to the selected dimensions were calculated. A strong, positive linear correlation was observed between general security and social security ( 0.837$)$, and between the general measure and the economic and financial component (0.826). Moreover, a weak, positive correlation was observed between the general synthetic measure of economic security and energy-food-ecological security (0.194). It can be assumed that the social, economic and financial dimensions 
have the most significant impact on shaping economic security, while the energy-food-ecological dimension has minor influence on determining the overall level of economic security.

The results obtained show, that level of economic security in selected dimensions is uneven throughout Poland. The reason for this situation is the diversity of regions in terms of economic development and the environment quality. It should be noted that some Voivodeships are more rural than others, and that determines the degree of interference in the environment.

\section{Conclusion}

The purpose of this study was to measure the level of economic security. The method developed by J. Perkal was applied in the research. The conducted research allowed the following conclusions to be drawn:

1. Not only are Polish Voivodeships diversified due to the general level of economic security, but also due to the level of economic security in individual dimensions.

2. The Mazowieckie Voivodeship is the most economically safe region in Poland. Its leader position in two dimensions (economic and financial and social) is unquestionable.

3. There is a difficulty identifying the weakest Polish region in terms of economic security level.

4. The most significant impact on determining general economic security has social, economic and financial dimensions.

5. In order to improve the economic security of Polish Voivodeships, it is necessary to increase their innovative potential in each dimension. What is crucial, the improvement process should not take place at the expense of the natural environment. Moreover development of economic security should take place in all dimensions at the same time, in a sustainable manner.

Further research needs to conduct more detailed analysis of the ecological dimension of economic security of Poland. It would be crucial to compare Poland's ecological security to other OECD countries. An attempt should be made to find the answer to the question: Is Poland still "catching up" or has it already "caught up" to the other OECD countries? 


\section{References}

\section{Books/Articles}

Borkowski M., Bezpieczeństwo Ekonomiczne Szwecji na tle państw OECD, Studia Ekonomiczne. Zeszyty Naukowe Uniwersytetu Ekonomicznego w Katowicach 2019/379 (17), pp. 7-31.

Buzan B., Waever O., de Wilde J., Security: A New Framework for Analysis, Lynne Rienner Publishers, London 1998.

Chybalski F., Analizy wielowymiarowe, in: I. Staniec (ed.), Metody ilościowe w zarzadzaniu organizacja, C.H. Beck, Warszawa 2013, pp. 86-105.

Dudin M.N., Fedorova I.J., Ploticina L.A., Tokmurzin T.M., Beyyaeva M.V., Ilyin A.B., International Practices to Improve Economic Security, European Research Studies Journal 2018/1, pp. 459-467.

Frejtag-Mika E., Kołodziejak Z., Putkiewicz W., Bezpieczeństwo ekonomiczne we współczesnym świecie, Stowarzyszenie na rzecz Ekorozwoju „Agro-Group”, Radom 1996.

Gierszewski J., Bezpieczeństwo społeczne jako dziedzina bezpieczeństwa narodowego, Historia i Polityka 2018/23 (30), pp. 21-38.

Grochowska R., Specyfika koncepcji bezpieczeństwa żywnościowego jako „problemu bez rozwiazania", Zagadnienia Ekonomiki Rolnej 2014/3, pp. 95-106.

Jaźwiński I., Determinanty ksztaltowania polskiego bezpieczeństwa gospodarczego. Wybrane aspekty, Przegląd Strategiczny 2011/1, pp. 59-70.

Kłosiński K.A., Światowe determinanty bezpieczeństwa ekonomicznego, in: T. Guz, K.A. Kłosiński, P. Marzec (eds.), Bezpieczeństwo ekonomiczne państw, Polihymnia, Lublin-Tomaszów Mazowiecki 2006, pp. 41-57.

Kostecka-Tomaszewska L., Economic Security of China in 21st centrury: SWOT analysis, in: H. Ribeiro, D. Naletina, A. Lorga de Silva (eds.), Economic and Social Development. Book of Proceedings, Economic and Social Development Conference 2018, pp. 486-496.

Kostecka-Tomaszewska L., Economic security of China: the implications of the belt and road initiative, Optimum. Economic Studies 2018/4 (94), pp. 166-182.

Kozlowska-Burdziak M., Warunki bezpieczeństwa żywnościowego Polski (ze szczególnym uwzględnieniem województwa podlaskiego), Optimum. Economic Studies 2019/3 (97), pp. 33-48.

Kruk H., Waśniewska A., Application of the Perkal method for assessing competitiveness of the countries of Central and Eastern Europe, Oeconomia Copernicana 2017/3, pp. 337-352.

Księżopolski K., Bezpieczeństwo ekonomiczne, Dom Wydawniczy ELIPSA, Warszawa 2011.

Leszczyńska M., Bezpieczeństwo ekonomiczne państwa a rozwój gospodarki i społeczeństwa, Nierówności Społeczne a Wzrost Gospodarczy 2018/46 (4), pp. 289-298.

Metelev S.E., Economic Security as a Scientific Category: Theoretical and Methodical Aspect of Research, Annales Universitatis Mariae Curie-Skłodowska 2014/39 (2), pp. 81-91.

Mikuła A., Bezpieczeństwo żywnościowe Polski, Roczniki Ekonomii Rolnictwa i Rozwoju Obszarów Wiejskich 2012/99/4, pp. 38-48.

Mkrtchyan T.M., State Economic Security System and Its Components, 4th Int'l Conference on Research in Humanities, Sociology \& Corporate Social Responsibility (RHSCSR'15), Penang 2015, pp. 10-12.

Namyślak B., Ocena potencjału kulturalnego największych miast Polski, Wiadomości Statystyczne $2013 / 6$, pp. 23-38. 
Niedziólka M., Bezpieczeństwo ekonomiczne państwa a funkcjonowanie otwartych funduszy emerytalnych, Zeszyty Naukowe Uniwersytetu Przyrodniczo-Humanistycznego w Siedlcach 2017/42 (115), pp. 227-235.

Nowak E., Metody taksonomiczne w klasyfikacji obiektów spoleczno-gospodarczych, Państwowe Wydawnictwo Ekonomiczne, Warszawa 1990.

Nowak E., Problemy doboru zmiennych do modelu ekonometrycznego, Państwowe Wydawnictwo Naukowe, Warszawa 1984.

Perkal J., O wskaźnikach antropologicznych, Przegląd Antropologiczny 1953/19, pp. 210-221.

Perło D., Environmental Quality as a Decisive Variable in Shaping Regional Development Policy, Studies in Logic, Grammar and Rhetoric 2014/37, pp. 159-178.

Perło D., Modelowanie zrównoważonego rozwoju regionów, Wydawnictwo Uniwersyteckie Trans Humana, Białystok 2014.

Pieters H., Vandeplas A., Guariso A., Francken N., Sarris A., Swinnen J., Gerber N., von Braun J., Torero M., Perspectives on relevant concepts related to food and nutrition security, Foodsecure, Working Paper 2012.

Reznikova N., Ecological imperatives for extension of globalisation processes: problem of economic security, „Інвестиції: практика та досвід 2016/21, pp. 23-26.

Roszkowska E., Filipowicz-Chomko M., Ocena rozwoju społecznego województw w latach 2005 oraz 2013 w kontekście realizacji koncepcji zrównoważonego rozwoju z wykorzystaniem metody TOPSIS, Ekonomia i Środowisko 2016/2 (57), pp. 134-149.

Skrabacz A., Uwarunkowania tworzenia bezpieczeństwa społecznego w XXI wieku, in: A. Skrabacz, S. Sulowski (eds.), Bezpieczeństwo społeczne. Pojęcie, uwarunkowania, wyzwania, Elipsa, Warszawa 2012, pp. 45-84.

Stachowiak B., Stachowiak Z., Kontrowersje i dylematy rozwiazania problemu bezpieczeństwa ekonomicznego w Polsce, Zeszyty Naukowe Akademii Obrony Narodowej 2014/3 (96), pp. 189-250.

Stachowiak Z., Bezpieczeństwo ekonomiczne, in: Z. Stachowiak (ed.), Ekonomika obrony, Akademia Obrony Narodowej, Warszawa 1994, pp. 180-188.

Stone M., Security According to Buzan: A Comprehensive Security Analysis, Security Discussion Papers. Series 1 2009/9, pp. 1-10.

Yong J., Economic Security: Redressing Imbalance, China Security 2007/2, pp. 66-85.

Żukrowska K., Bezpieczeństwo międzynarodowe. Przegląd aktualnego stanu, Wydawnictwo IUSatTAX, Warszawa 2011.

Żukrowska K., Pojęcie bezpieczeństwa i jego ewolucja, in: K. Żukrowska, M. Grącik (eds.), Bezpieczeństwo międzynarodowe. Teoria i praktyka, Wydawnictwo Szkoła Główna Handlowa, Warszawa 2006, pp. 7-24.

\section{Statistical data}

Local Data Bank, Statistics Poland (Główny Urząd Statystyczny), https://bdl.stat.gov.pl/BDL/ start; accessed 22.11.2019. 


\section{Mateusz BORKOWSKI}

\section{BEZPIECZEŃSTWO EKONOMICZNE POLSKICH WOJEWÓDZTW. KONCEPCJA POMIARU}

\section{Abstrakt}

Przedmiot badań: Współcześnie bezpieczeństwo ekonomiczne należy do najważniejszych kwestii w analizie gospodarek. Można uznać, że pomiar i ocena bezpieczeństwa ekonomicznego jest swego rodzaju holistycznym badaniem całej gospodarki.

Cel badawczy: W artykule podjęto próbę pomiaru bezpieczeństwa ekonomicznego polskich województw, zarówno w jego poszczególnych wymiarach, jak i w sposób ogólny.

Metoda badawcza: Do budowy syntetycznych indykatorów wykorzystano jedną z technik taksonomicznych: metodę miary Perkala.

Wnioski: Opracowane syntetyczne wskaźniki bezpieczeństwa ekonomicznego pozwoliły na uporządkowanie województw pod względem tego zjawiska. Polskie województwa są nie tylko zróżnicowane ze względu na ogólny poziom bezpieczeństwa ekonomicznego, ale także na poziom bezpieczeństwa w poszczególnych wymiarach. Co więcej, istniała możliwość wyznaczenia współczynników korelacji pomiędzy indykatorem ogólnego bezpieczeństwa ekonomicznego a miernikami tego zjawiska z poszczególnych wymiarach. Największy wpływ na kształtowanie ogólnego poziomu bezpieczeństwa mają wymiary: społeczny oraz ekonomiczny i finansowy.

Słowa kluczowe: bezpieczeństwo ekonomiczne, wymiary bezpieczeństwa ekonomicznego, metoda Perkala. 